\title{
CASP8*1 Allele
}

National Cancer Institute

\section{Source}

National Cancer Institute. CASP8*1 Allele. NCI Thesaurus. Code C68810.

Human CASP8* 1 allele is a variant form of the CASP8 gene which is located within 2q33q34 and is approximately $54 \mathrm{~kb}$ in length. The wild-type allele, which encodes caspase- 8 protein, is involved in apoptosis regulation. CASP8*1 allele exhibits a SNP (c.1207G>C) that results in a $\mathrm{D} 302 \mathrm{H}$ coding change, which may reduce the activity of the encoded protein. This variant may reduce the incidence of breast cancer in subjects who carry this allele. 